\title{
Study of Total Lactic Acid Bacteria (LAB) and Antioxidant Activity in Goat Milk Yoghurt Fortified by White Rice Bran Flour
}

\author{
Ajeng Erika Prihastuti Haskito \\ Veterinary Public Health Laboratory, \\ Faculty of Veterinary Medicine, Brawijaya University \\ Malang Indonesia \\ drherika1989@gmail.com
}

\author{
Masdiana Chendrakasih Padaga \\ Veterinary Public Health Laboratory, \\ Faculty of Veterinary Medicine, Brawijaya University \\ Malang Indonesia \\ drherika1989@gmail.com
}

\begin{abstract}
Yogurt is one of functional fermented food products from milk created by the addition of Lactic Acid Bacteria (LAB) which has many health benefit. Goat milk yogurt has components of bioactive peptides with antioxidants potency. Antioxidant derivatives of bioactive peptides in goat milk yogurt include proline, histidine, tyrosine, and tryptophan. Rice bran is a by-product of rice mills which have good nutritional content and are rich in bioactive components, one of which has antioxidant activity. Antioxidant compounds found in white rice bran can be grouped into 8 groups: phenolic acids, flavonoids, anthocyanins, proanthocyanins, tocopherols, tootrienols, $\gamma$ oryzanol, and phytic acid. The objective of this study was to observe total LAB of goat milk yoghurt fortified by white rice bran flour. This was a true experimental study with two factor treatments and five repitition. Yoghurt was made by adding starter which contained Lactobacillus bulgaricus, Streptococcus thermophilus, and Lactobacillus acidophilus. Total LAB was analyzed using Total Plate Count (TPC) and analysis of the antioxidant activity was done by 2,2-diphenyl1-picrylhydrazyl (DPPH) test. Results showed that fortification by white rice bran flour in goat milk yoghurt could increase total LAB and antioxidant activity.
\end{abstract}

Keywords - antioxidant, goat milk, LAB, white rice bran, yoghurt

\section{INTRODUCTION}

Rice bran, a by-product, has garnered increasing attention as functional food in the last few years. This is related to rice bran functionality on body health (Tuarita et. al., 2017). Rice bran is a by-product of rice milling, obtained from the outer layer of rice seed caryopsis (Henderson et. al., 2012). Until now, rice bran development effort as functional food is still hindered by several problems, among them are the lack of awareness in the community on rice bran benefits, much of rice bran still used solely as livestock feed, the yet standardized rice bran quality and the lack of interest from downstream industry to develop rice bran. This becomes a particular challenge for rice bran development considering its promising potential for human health (Tuarita et. al., 2017).

Rice bran role as functional food source with a potential to improve health can be seen from its bioactive components and fiber content. The type of food fiber contained in rice bran are cellulose, hemicellulose, pectin, arabinoxylan, lignin, and $\beta$-glucan. Rice bran bioactive component consists of $\gamma$-oryzanol, ferulic acid, caffeic acid, tricine, kumaric acid, phytic acid, vitamin $\mathrm{E}$ isoforms ( $\alpha$-tocopherol, $\gamma$-tocopherol, tocotrienol), phytosterol $(\beta$ sitosterol, stigmasterol, campesterol), dan karotenoid ( $\alpha$ karoten, $\beta$-karoten, lutein, likopen) (Henderson et. al. 2012).

Rice bran is rich with antioxidant and thus has the potency as a defense against free radical. Antioxidant compounds found in rice bran can be group into 8 groups: phenolic acid, flavonoid, anthocyanin, proanthocyanin, tocopherol, tocotrienol, $\gamma$-oryzanol, and phytic acid (Tuarita et. al., 2017). The main antioxidant of rice bran is $\gamma$-oryzanol. Antioxidant $\gamma$-oryzanol is composed of the mix of esters ferulic acid and phytosterol. At least ten esters of ferulic acid has been identified in $\gamma$-oryzanol; cycloartenyl ferulate, 24-methylenecycloartanyl ferulate, campestenyl ferulate, campesteryl ferulate, stigmastenyl ferulate, sitosteryl ferulate, 7-stigmatenyl ferulate, stigmateryl ferulate, campestanyl ferulate, and sitostanyl ferulate. Among those compounds, cycloartenyl ferulate, 24methylenecycloartanyl ferulate, campestenyl ferulate, and sitosteryl ferulate are the most dominant compounds (Minatel et. al., 2016).

The same findings were reported from goat milk studies. Goat milk has several advantages compared to cow milk, especially in health aspects. Goat milk is source of bioactive peptides, making it also has the potential to be developed as functional food with the right processing technology, such as fermentations. Lactic Acid Bacteria (LAB) possesses proteolytic enzyme that can hydrolyze bioactive peptide binding to precursor proteins to detach and thus produce processed milk product with relatively high bioactive peptide compounds. Among the biological functions of known bioactive peptides is antioxidant (Awemu et. al., 2009).

Several milk bioactive peptides are known to play a role in body oxidative metabolism, which maintain the life of cells. Milk bioactive peptide antioxidant derivates consists of five to eleven hydrophobic amino acids, among them are proline, histidine, tyrosine, and tryptophan- 
especially those that have been hydrolyzed my proteolytic enzyme activity. These bioactive peptide antioxidant derivates have the ability to prevent cellular component damage by inhibiting the formation of free radical and by exhibiting scavenging radical effect (Mohanty et. al., 2015)

Based on those facts, potency exploration in goat milk fermented into yoghurt product fortified or added by white rice bran is required to create it into natural functional food with LAB and antioxidant content. This experiment is hoped to strengthen national innovation system in developing natural functional processed based food product of goat milk fermentation fortified by white rice bran flour.

\section{MATERIALS AND METHODS}

\section{A. Yoghurt production}

Yoghurt production began by creation of working mother culture, which is the addition of starter powder (Yogourmet $^{\circledR}$ contained Lactobacillus bulgaricus, Streptococcus thermophilus, and Lactobacillus acidophilus) as much as 0.35 gram into $70 \mathrm{ml}$ of pasteurized goat milk and incubated in $45^{\circ} \mathrm{C}$ temperature for 4 hours until it reached $\mathrm{pH}$ 4.4-4.5. The processed was followed by (1) yoghurt making by adding $3 \%$ working mother culture into $480 \mathrm{ml}$ of pasteurized goat milk and (2) yoghurt making by adding $3 \%$ working mother culture and $4 \%$ white rice bran flour into $480 \mathrm{ml}$ pasteurized goat milk and then incubated in $45^{\circ} \mathrm{C}$ temperature for 4 hours until they reached $\mathrm{pH}$ 4.5-5.

\section{B. LAB Total Test}

Goat milk yoghurt and goat milk yoghurt fortified by $4 \%$ white rice bran flour was tested for LAB by total plate count method. Total plate count method most often used to count the amount of microorganism inside food stuff. From desired yoghurt dilution, $1 \mathrm{ml}$ yogurt was poured into petri dish and then $30 \mathrm{ml}$ of liquid agar medium was poured after. After the agar medium solidified, the plates were incubated for 24 hours for bacterial colony growth, which then counted.

\section{Antioxidant activity test}

Goat milk yoghurt and goat milk yoghurt fortified by $4 \%$ white rice bran flour extracted by methanol were reacted with DPPH solution for 30 minutes. The antioxidant activity of goat milk yoghurt fortified by $4 \%$ white rice bran flour was measured as $(\%)$ discoloration.

\section{RESULTS}

After data were obtained, data processing was done by Microsoft Excel 2010 software. Data was presented as graphic which showed the average value of the 5 repetition of each treatment. Total LAB test was done by Total Plate Count method. The result of total LAB from goat milk yoghurt and goat milk yoghurt fortified by white rice bran flour was shown in Fig. 1.

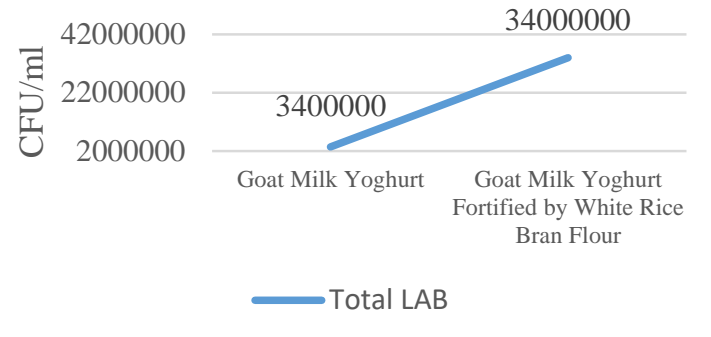

Fig. 1. Average Total Count of Lactic Acid Bacteria (Lab)

The result of antioxidant activity test from goat milk yoghurt and goat milk yoghurt fortified by white rice bran is shown on Fig. 2.

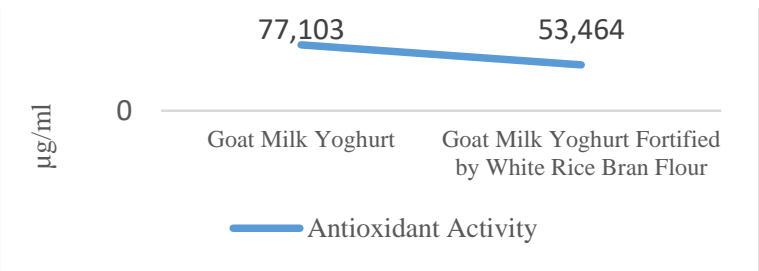

Fig. 2. Average Value of Antioxidant Activity

\section{DISCUSSION}

Lactic Acid Bacteria (LAB) is a type of bacteria important in processing probiotic beverages. The total number of Lactic Acid Bacteria (LAB) in a given probiotic beverage determine the quality of the said probiotic beverage (Agustine et. al., 2018). Yoghurt is a probiotic beverage product obtained by fermenting milk with LAB. During its processing, a single culture or mixed culture of LAB can be used (Rahman et. al., 2015). Lactobacillus bulgaricus and Streptococcus thermophilus are two type of bacteria most often used as yoghurt starter. If both bacteria used at the same time as yoghurt starter, they would form mutualism symbiosis. Lactobacillus bulgaricus produces amino acid and short peptides which induce the growth of Streptococcus thermophilus, which produces formic acid that support the growth Lactobacillus bulgaricus (Effendi et. al., 2009). Burton et. al., (2014) stated that according to SNI 2981:2009, the appropriate number of LAB in yoghurt is $10^{7} \mathrm{CFU} / \mathrm{ml}$, while according to $\mathrm{WHO} / \mathrm{FAO}$, the minimum $\mathrm{LAB}$ requirement for probiotic is $10^{6}-10^{8}$ $\mathrm{CFU} / \mathrm{ml}$. The number of $\mathrm{LAB}$ in probiotic beverage consumed as health improvement drink is $10^{6}-10^{9} \mathrm{CFU} / \mathrm{ml}$. From the result of this research it can be known that the average total of LAB from goat milk yoghurt made out of starter containing LAB Lactobacillus bulgaricus, Streptococcus thermophilus, and Lactobacillus acidophilus was $3,4 \times 10^{6} \mathrm{CFU} / \mathrm{ml}$. The result showed that goat milk yoghurt is within good quality health beverage. The average total LAB of goat milk yoghurt fortified by white rice bran flour was $3,4 \times 10^{7} \mathrm{CFU} / \mathrm{ml}$. The result showed an increase of LAB total count. Zubaidah et. al., (2010) studied the comparison of LAB total in rice bran and skim milk fermented by probiotic LAB, which showed that rice bran fermentation media had higher number of LAB compared to skim milk fermentation media. This is assumed to be caused by more complete nutrition content 
in rice bran. In goat milk yoghurt fortified by white rice bran, nutrition source used by LAB during fermentation process was more complex, because of combined carbohydrate, protein, and fiber obtained from both goat milk and white rice bran flour. Zubaidah et. al., (2014) stated that nutrition such as carbohydrate, protein, and fiber are used by LAB as energy source for growth, cell formation, and biosynthesis of metabolite products.

Antioxidant is a chemical compound that can provide one or more electron to free radicals, which would inhibit the free radical (Husni et. al., 2015). Antioxidant compound in food stuff plays an important role as a defense factor of health (Abbas et. al., 2016). From this research, it is known that the antioxidant activity of goat milk yoghurt fortified by white rice bran $(53,464)$ was higher compared to average antioxidant activity of goat milk yoghurt (77.103). A compound is considered to be very strong antioxidant if its $\mathrm{IC}_{50}$ value $<50 \mu \mathrm{g} / \mathrm{ml}$; strong if $\mathrm{IC}_{50}$ value $50-100 \mu \mathrm{g} / \mathrm{ml}$; moderate if $\mathrm{IC}_{50}$ value $250-500$ $\mu \mathrm{g} / \mathrm{ml}$; weak if $\mathrm{IC}_{50}$ value > $500 \mu \mathrm{g} / \mathrm{ml}$; (Werdhasari, 2014). Thus, it can be concluded that the antioxidant activity contained in goat milk yoghurt fortified by white rice bran flour is classified as very strong antioxidant. This is in in accordance with a research by Samichah (2014), who studied the antioxidant activity of carrot extract is high, especially with $20 \%$ addition of carrot extract. This showed that the addition of natural compound such as fruit, vegetable, and grain, may increase antoxidant activity and thus can be utilized as antioxidant food source which can function as consumer's defense against diseases caused by free radicals and oxidative stress (Samichah, 2004; Zubaidah et. al., 2010; Abbas et. al., 2016). Antioxidant activity of rice grain is strongly influenced by phenolic and anthocyanin compounds. The more phenolic and anthocyanin compounds, the higher its antioxidant activity. Compared to other rice grain, white rice grain has the lowest content of phenolic and anthocyanin compound for it also has the lowest level of pigmentation. Phenolic compounds in rice bran are tocopherol, tocotrienol, $\gamma$ oryzanol, $\beta$-sitosteril ferulat, which bind with insoluble fiber (Tuarita et. al., 2017). Fiber degradation by LAB happened during fermentation process, forming simpler compound and causing covalent bond between phenolic compound and insoluble fat to break, and thus increase the antioxidant bioavailability of rice bran (Zubaidah et. al., 2010). Abbas et. al., (2016) stated that antioxidant from phenolic compound worked by lowering the concentration of radical oxygen and prevent initiation by capturing free radicals such as hydroxyl radicals. Goat milk itself contains various bioactive compounds, whose concentration can be increased by fermentation. Several bioactive compound in goat milk can lower DNA damage, especially those caused by free radicals. These bioactive compounds are lactopherin, like-laktoferin, and other peptides with antioxidant activity. These bioactive compounds are very heat sensitive, which may denaturize protein. However, fermentation process will produce novel peptides or bioactive peptides (Khan et. al., 2019).

\section{ACKNOWLEDGMENT}

Gratitude is given to Badan Penelitian dan Pengabdian Masyarakat (Research and Community Service Agency), Faculty of Veterinary Medicine, Brawijaya University, Malang, for the research grant DPP-SPP Year 2019 and Veterinary Public Health Laboratory, Faculty of Veterinary Medicine, Brawijaya University, Malang, for the facilities during the course of this research.

\section{REFERENCES}

[1] A. J. Henderson, C. A. Ollila, A. Kumar, E. C. Borresen, K. Raina, R. Agarwal, and E. P. Ryan, Chemopreventive properties of dietary rice bran : currrent status and future prospect, advances in nutrition an international review journal, vol. 3, pp. 643-653, September 2012

[2] A. Husni, M. Madalena, and Ustadi, Antioxidant activity and consumer preference of yoghurt enriched with sargassum polycystum extract, Indonesian fisheries processing journal, vol. 18, no. 2 , pp. 108-118. 2015.

[3] A. Werdhasari, The role of antioxidant for health, The Indonesian journal of biotechnology medicine, vol. 3, no. 2, pp.59-68, August 2014.

[4] D. P. Mohanty, S. Mohapatra, S. Misra, and P. S. Sahu, Milk derived bioactive peptida and their impact on human health-a review, Journal of biological sciences. Pp. 1-7, 2015.

[5] E. Burton, I. I. Arief, and E. Taufik, Functional properties of carbonated probiotic yoghurt, Journal of animal production and processing technology, vol. 2, no. 1, pp. 213-218, January 2014.

[6] E. M. I. Awemu, J. R. Liu, and X. Zhao, Bioactive components in yoghurt products, Bioactive components in milk and dairy products text book, 235-250, 2009

[7] E. Zubaidah, N. Aldina, and F. C. Nisa, Study on antioxidant activity of fermented rice bran and skim milk by probiotic lactic acid bacteria (Lactobacillus plantarum J2 and Lactobacillus casei), Jurnal Teknologi Pertanian, vol. 11, no. 1, pp. 11-17, April 2010.

[8] E. Zubaidah, E. Martati, and A. M. Resmanto, Growth of LAB isolated from rice bran and corn mercial probiotic (Lactobacillus acidophillus and Lactobacillus casei) on rice bran and skimmed milk media, Indonesian journal of biotechnology and Bioscience, vol. 1 , no. 1 , pp. 27-37, 2014.

[9] H. M. Abbas, A. M. S. Hussien, and G. E. Ibrahim, Changes in antioxidant activity and volatile compounds of functional yoghurt fortified with rice bran during storage", Journal of chemical and pharmaceutical research, vol. 8, no. 7, pp. 761-766, 2016.

[10] I. G. Minatel, F. V. Francisqueti, C. R. Correa, and G. P. P. Lima, Antioxidant activity of $\gamma$-orizanol : a complex network of interactions, International journal of moleculer science, vol. 17, pp. 1107-1121. 2016.

[11] I. T. Khan, M. Nadeem, M. Imran, R. Ullah, M. Ajmal, and M. H. Jaspai. Antioxidant properties of milk and dairy products : a comprehensive review of the curent knowledge, Lipids in health and disease journal, vol. 18, no. 41, pp. 1-13, February 2019.

[12] L. Agustine, Y. Okfrianti, and Jumiati, "Total identification of lacktat acid bacteria (LAB) in yoghurt with various sukrosa and skim milk", Journal of the world of nutrition , vol. 1, no. 2, pp. 7983, December 2018.

[13] M. H. Effendi, S. Hartini, and A. M. Lusiastuti, Increasing yoghurt quality froam goats milk by adding skim milk powder and managing incubation temperature, Jurnal Penelitian Medika Eksata, vol. 8, no. 3, pp. 185-192, December 2009.

[14] M. Z. Tuarita, N. F. Sadek, S. Sukarno, N. D. Yuliana, and S. Budijanto, Rice bran development as functional foods : the opportunities, obstacles, and challenge, Jurnal Pangan, vol. 26, no. 2, pp. 1-11, August 2017.

[15] S. D. Rahman, S. Djajasoepena, D. S. Kamara, I. Idar, R. Sutrisna, A. Safari, O. Suprijana, and S. Ishmayana, Quality of yoghurt made by two culture (Lactobacillus bulgaricus dan Streptococcus thermophilus) and three bacterias (Lactobacillus bulgaricus, Streptococcus thermophilus, dan Lactobacillus acidophilus), Chimica et natura acta, vol. 2, no. 2, pp. 76-79, August 2015.

[16] S. Samichah, and A. Syauqy, Antioxidant activity and organoleptic acceptance of yohurt with carrot juice, Journal of nutrition collage, vol. 3 , no. 4, pp. 501-508. 2014. 